\title{
MENENTUKAN JUMLAH PRODUKSI KAYU BARE CORE MENGGUNAKAN METODE PERENCANAAN ZERO INVENTORY
}

\author{
Widiyarini \\ Dosen Program Studi Tehnik Industri FTIK \\ Universitas Indraprasta PGRI Jakarta \\ Email : widiya2513@ymail.com
}

\section{ARTICLE INFO}

Keywords:

bare core, production plan, zero inventory.

\author{
ABSTRACT
}

\begin{abstract}
Encountering the playwood industry competition, companies have to maintain the production flow by producing good quality products, exact production time, and lower production cost. A timber factory that produces bare core in the difficulty to deal with the challenge which is caused by the amount of the work forces that are not proportional with the goods which are being produced, and also bad decision of work time causing the high number of salary to the income of the company become lower. The effort that have to be done are adjust the number of the work force and standard time in order to be proportional to the goods which are going to be produced. Through the zero inventory method, company will only produce goods that are needed by the consumers.The number of the work force will increase when the demand is increasing and will lower the work force when the demand is discreasing, Production plan analysis is conducted to ease the work force number determining process. Hence, the at last the minimum cost production could be determined.

The calculation result shows that the costs which are spent by the company on May 2017 is the highest in the amount of Rp 2.306.804 and the lowest cost spent is on December 2017 in the amount of Rp. 1.545.906.000.This strategy is proposed based on the cost calculation which is more precisely spent, resulting to minimized spending and limited without cost calculation, recruiting investment, and workforce training.
\end{abstract}

\section{PENDAHULUAN}

Situasi ekonomi dunia saat ini berpengaruh terhadap perkembangan industri dalam negeri, terutama berkaitan dengan peningkatan permintaan pasar internasional terhadap produk dalam negeri. Berita yang termuat di dalam agroindonesia.co.id memberikan contoh dampak perang dagang antara AS dan China, dengan ditetapkannya keputusan Departemen Perdagangan AS yang menerapkan Bea Masuk Antidumping (BMAD) dan Bea Masuk Imbalan (Countervailing Duty) terhadap produk kayu lapis (plywood)China membuka peluang besar Indonesia merebut kembali pasar plywoodAmerika. Demikian juga dengan kebijakan peningkatan kerja sama bilateral antara Indonesia dan Korsel menjadi Special Strategic Partnership. Berdasarkan artikel Kompas.com dengan judul Ekspor Kayu Lapis ke Korsel, Pasar Menggiurkan bagi Indonesia, pada tahun 2016 Korsel mengimpor 29,9\% total kebutuhan kayu lapis dari Indonesia dan permintaan tersebut hingga tahun 2018 terus mengalami 
peningkatan.Permintaan pasar kayu lapis di AS, Korsel dan negara lainnya tentu sangat berpengaruh terhadap pertumbuhan industri pengolahan kayu lapis dalam negeri yang pada akhirnya menyebabkanterjadinya persaingan antara parapelaku industri di bidang ini karena masing-masing berusaha merebut pasar, dalam bentuk persaingan kualitas maupun persaingan harga.Menghadapi kondisi persaingan ini, perusahaan harus bisa menjaga kelancaran produksi dengan menghasilkan produk yang berkualitas, waktu proses pembuatan yang tepat, dan ongkos produksi yang lebih murah.

Perencanaan agregat pada sebuah perusahaan pengolahan kayu barecore, secara khusus dengan cara melakukan pengagregasian produk yaitu dengan mengkonversikan produk-produk yang diproduksi pada periode perencanaan ke dalam satu jenis produk yang dipilih sebagai produk agregat. Agregasi produk hanya bisa dilakukan apabila terdapat kesamaan penggunaan fasilitas produksi dari kebutuhan sumber-sumber yang digunakan dalam proses produksi misalnya kebutuhan mesin, peralatan, bahan baku dan tenaga kerja.

Namun kondisi yang dijumpai adalah perusahaan kesulitan untuk menghadapi tantangan persaingan akibat dari jumlah tenaga kerja tidak sebanding dengan jumlah barang yang diproduksi mengakibatkan tingginya pembayaran upah tenaga kerja sehingga pendapatan perusahaan menjadi rendah. Selain itu penentuan waktu standar kurang tepat karena hanya didasari observasi langsung tanpa melakukan perhitungan secara ilmiah.

Penelitian sebelumnya yang dilakukan oleh Ming Lei, Zihan Yin, \&Shalang Li. (2017) berjudul Intermittent demand forecasting and inventory control with multiple temporal and cross-sectional aggregation and disaggregation methods yang mengkaji metode peramalan permintaan intermiten dan membandingkan beberapa metode perkiraan agregasi dan disaggregasi temporal dan metode perincian agregasi dan disagregasi crosssectional dan kemudian mengusulkan metode peramalan baru dengan menggabungkan kedua metode ini. Dengan menggunakan data pengadaan dari State Grid Corporation of China untuk mempelajari metode peramalan permintaan ini. Dalam hal kinerja peramalan, digunakan dua pengukuran kesalahan perkiraan serta simulasi simulasi persediaan data berbasis nyata. Hasil studi kasus menunjukkan bahwa beberapa metode perkiraan agregasi dan disaggregasi temporal akan menghasilkan kesalahan peramalan yang lebih kecil daripada metode pemulusan eksponensial dan metode peramalan cross-sectional dan metode peramalan gabungan akan memiliki kinerja inventarisasi yang lebih baik daripada metode peramalan sebelumnya.Penelitian yang dilakukan oleh Carlos, A.C., \& Zuluaga. (2012) menggunakan metode model matematis dan spreadsheet. Metodeini digunakan untuk mengontrol persediaan barang dan meminimalkan biaya. Sedangkan penelitian yang dilakukan oleh Hanczar, P. B., \& Jakubiak, M. (2011) melakukan model pemrograman dan perencanaan agregrat untuk mengusulkan jumlah produksi. Sangat bagus dalam perencanaan produksi keseluruhan.

Upaya penyelesaian dilakukan dengan cara menyesuaikan jumlah tenaga kerja agar sebanding dengan jumlah barang yang diproduksi sehingga pembayaran upah tenaga kerja menjadi lebih rendah, disertaipenentuan waktu standar yang tepat didasari perhitungan secara ilmiah.

Tulisan ini berusaha menjelaskan tentang perencanaan zero inventorydalam cakupan periode perencanaan, perusahaan hanya memproduksi sejumlah yang dibutuhkan.

Konsumen dengan tidak mengikutsertakan persediaan. Jumlah tenaga kerja akan bertambah ketika kebutuhan permintaan naik dan akan dilakukan pengurangan tenagakerja ketika kebutuhan atau permintaan menurun. 
Perusahaan harus terus melakukan perencanaan dengan kualitas barang yang baik sesuai permintaan konsumen. Jenis produk yang dihasilkan oleh perusahaan tersebut adalah jenis kayu olahan yaitu albasia bare core. Bare core yaitu kayu lapis yang tersusun atas potongan-potongan kayu dengan ukuran panjang $50 \mathrm{~cm}$ dan $40 \mathrm{~cm}$ yang direkatkan satu dengan yang lainnya dan dilapisi dengan vinir (triplek). Ukuran bare core yang dihasilkan adalah:ketebalan $13 \mathrm{~mm}$ x $1220 \mathrm{~mm}$ x $2440 \mathrm{~mm}$, ketebalan $15 \mathrm{~mm}$ x $1220 \mathrm{~mm}$ x $2440 \mathrm{~mm}$, dan ketebalan 16 $\mathrm{mm} \times 1220 \mathrm{~mm} \times 2440 \mathrm{~mm}$.

\section{METODE}

Penelitian dilakukan terhadap perusahaan kayu yang berada di Bogor difokuskan pada Departemen Planning Production and Inventory Control melalui wawancara dan diskusi dengan Manager dan Team Planning Production and Inventory Control, Manager Keuangan dan pihak perusahaan yang ahli, termasuk operator di bagian produksi. Diskusi dilakukan untuk mengetahui kondisi umum dan mengidentifikasi permasalahan yang dihadapi oleh perusahaan.

\section{Menghitung Waktu Standar}

Langkah yang dilakukan dalam menentukan waktu standar sebagai berikut:

1. Penentuan waktu rata-rata.Penentuan waktu rata-rata (waktu siklus), dengan cara membagi jumlah semua data yang telah diambil dengan banyaknya jumlah pengamatan.

2. Penentuan waktu normal. Waktu normal didapat dengan cara mengalikan rata-rata waktu siklus dengan faktor penyesuaian dari operator yang telah dinormalkan. Faktor penyesuaikan sama dengan satu apabila pekerja bekerja dengan wajar. Jika oprator bekerja terlalu lambat maka, untuk menormalkannya faktor penyesuaian harus lebih dari satu.

3. Penentuan waktu standar.Waktu standar ditentukan dari waktu normal ditambah perkalian antara kelonggaran dengan waktu normal. Nilai kelonggaran yang dimasukkan dan diperhitungkan terdiri atas kelonggaran untuk kebutuhan pribadi, kelonggaran untuk menghilangkan rasa lelah, kelonggaran untuk hambatan-hambatan tak terhindarkan.

\section{Menghitung Man Hours}

Setelah menghitung waktu standar, kemudian selanjutnya dapat dihitung jumlah man hours (jam tenaga kerja). Jam tenaga kerja dihitung dengan menggunakan data jumlah produksi periode tertentu, dikalikan dengan data waktu penyelesaian produk untuk satu unit produk.

\section{Menghitung Unit Agregasi}

Cara melakukan pengagregasian produk yaitu dengan mengkonversikan produk-produk yang diproduksi pada periode perencanaan ke dalam satu jenis produk yang dipilih sebagai produk agregat. Agregasi produk hanya bisa dilakukan apabila terdapat kesamaan penggunaan fasilitas produksi dari kebutuhan sumber-sumber yang digunakan dalam proses produksi misalnya kebutuhan mesin, peralatan, bahan baku dan tenaga kerja. 


\section{Menghitung Jam Kerja Tersedia dan Kebutuhan Tenaga Kerja}

Setelah melakukan agregasi kemudian dapat dihitung jam kerja tersedia. Dalam memenuhi target produksi diperlukan gambaran mengenai jam yang tersedia pada setiap bulan. Dimana jumlah jam kerja produktif tiap harinya adalah delapan jam dengan ketentuan sebagai berikut:

1. Untuk mendapatkan jam kerja yang tersedia selama satu tahun dilakukan dengan cara mengalikan jumlah hari kerja dengan jam kerja regular.

2. Sedangkan untuk menghitung kebutuhan tenaga kerja dapat dilakukan dengan membagi total jam tenaga kerja dengan total jam kerja yang tersedia.

\section{Penyusunan Rencana Produksi}

Analisa rencana produksi dilakukan untuk memudahkan dalam menganalisis jumlah tenaga kerja yang diperlukan. Sehingga pada akhirnya dapat ditentukan besarnya biaya produksi dari penggunaan perencanaan produksi yang menghasilkan biaya produksi paling minimal. Perencanaan produksi dapat digunakan sebagai alat untuk pengambilan keputusan. Metode perencanaan produksi yang digunakan dalam penulisan ini adalah metode Zero Inventory Plan (perencanaan produksi tanpa menggunakan persediaan). Perencanaan zero inventory sering disebut juga perencanaan lot for lot, perusahaan hanya memproduksi sejumlah yang dibutuhkan konsumen dengan tidak mengikutsertakan persediaan. Jumlah tenaga kerja akan bertambah ketika kebutuhan permintaan naik dan akan dilakukan pemutusan hubungan kerja ketika kebutuhan atau permintaan menurun. Biaya-biaya yang terkait dengan metode ini antara lain biaya pengangkatan tenaga kerja, biaya pemutusan tenaga kerja, biaya jam kerja biasa, dan harga jual produk.

\section{Kerangka Penelitian}

Kerangka penelitian merupakan tahapan atau langkah-langkah dari keseluruhan penelitian yang dilakukan. Bagan kerangka penelitian dapat dilihat pada gambar berikut:

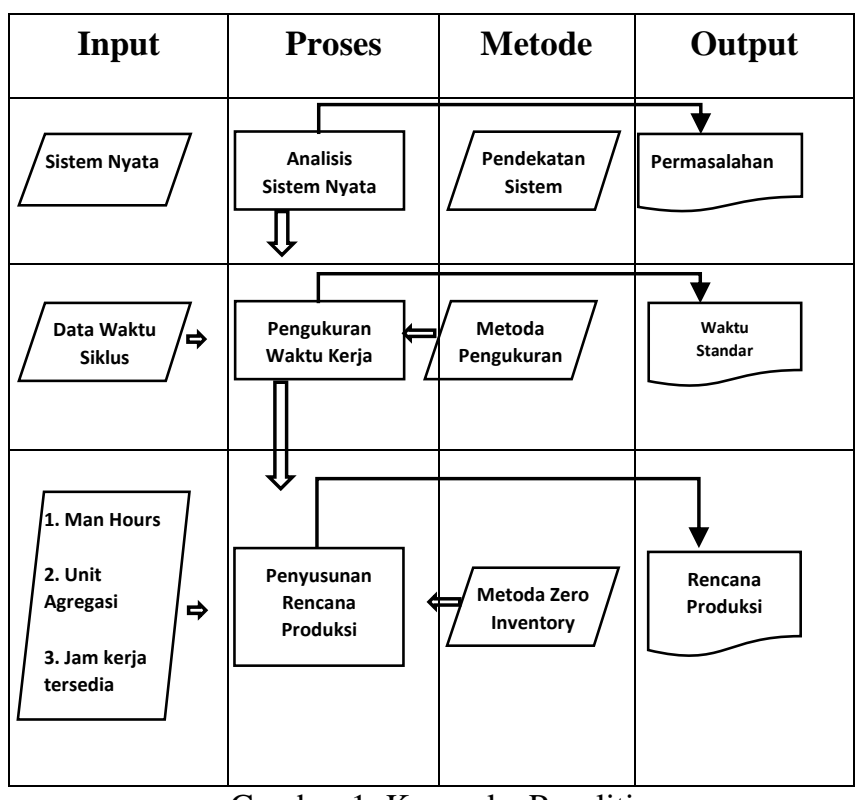

Gambar 1. Kerangka Penelitian 


\section{HASIL DAN PEMBAHASAN}

\section{Analisis Waktu Standar}

Waktu siklus merupakan waktu kegiatan produktif yang diperoleh dari hasil pengamatan langsung menggunakan stopwach. Sebelum waktu siklus ini diolah untuk mendapatkan waktu standar, terlebih dahulu dilakukan pengujian-pengujian untuk mengetahui valid atau tidaknya data waktu siklus tersebut. Dari data tersebut dilakukan uji kenormalan data, pengujian dinyatakan normal, apabila nilai p-value > 0,05 (lihat tabel 1sampai 2).

Tabel 1. Uji Kenormalan Data Bare Core $13 \mathrm{~mm}$

\begin{tabular}{clcccccc}
\hline No & \multicolumn{1}{c}{ Stasiun Kerja } & Subgrup & Mean & $\begin{array}{c}\text { Standar } \\
\text { Deviasi }\end{array}$ & KS & $\begin{array}{c}\text { P- } \\
\text { Value }\end{array}$ & $\begin{array}{c}\text { Hasil } \\
\text { Pengujian }\end{array}$ \\
\hline 1 & Pemotongan Balok Kayu & 6 & 5,50 & 0,1147 & 0,215 & 0,150 & Normal \\
2 & Penyerutan Dua Sisi Kayu Balok & 6 & 5,82 & 0,03656 & 0,197 & 0,150 & Normal \\
3 & Pembelahan Kayu Balok & 6 & 5,68 & 0,12530 & 0,179 & 0,150 & Normal \\
4 & Sortir & 6 & 2,95 & 0,05269 & 0,271 & 0,150 & Normal \\
5 & Penyusunan Kayu & 6 & 5,54 & 0,01169 & 0,140 & 0,150 & Normal \\
6 & Pemotongan Susunan Kayu & 6 & 5,04 & 0,04262 & 0,225 & 0,150 & Normal \\
7 & Pengeleman Pengepresan & 6 & 5,88 & 0,04719 & 0,195 & 0,150 & Normal \\
8 & Revisi & 6 & 2,64 & 0,13430 & 0,273 & 0,150 & Normal \\
9 & Pemotongan Ukuran Bare Core & 6 & 3,22 & 0,11940 & 0,202 & 0,150 & Normal \\
10 & Packing & 6 & 5,64 & 0,13430 & 0,273 & 0,150 & Normal \\
\hline
\end{tabular}

Tabel 2. Uji Kenormalan Data Bare Core $15 \mathrm{~mm}$

\begin{tabular}{clcccccc}
\hline No & \multicolumn{1}{c}{ Stasiun Kerja } & Subgrup & Mean & $\begin{array}{r}\text { Standar } \\
\text { Deviasi }\end{array}$ & KS & P-Value & $\begin{array}{c}\text { Hasil } \\
\text { Pengujian }\end{array}$ \\
\hline 1 & Pemotongan Balok Kayu & 6 & 5,61 & 0,03987 & 0,117 & 0,150 & Normal \\
2 & Penyrutan Dua Sisi Kayu Balok & 6 & 5,69 & 0,04535 & 0,179 & 0,150 & Normal \\
3 & Pembelahan Kayu Balok & 6 & 5,65 & 0,07633 & 0,197 & 0,150 & Normal \\
4 & Sortir & 6 & 3,00 & 0,11500 & 0,233 & 0,150 & Normal \\
5 & Penyusunan Kayu & 6 & 5,59 & 0,06947 & 0,149 & 0,150 & Normal \\
6 & Pemotongan Susunan Kayu & 6 & 5,17 & 0,09266 & 0,238 & 0,150 & Normal \\
7 & Pengeleman Pengepresan & 6 & 5,95 & 0,08735 & 0,156 & 0,150 & Normal \\
8 & Revisi & 6 & 3,01 & 0,04131 & 0,146 & 0,150 & Normal \\
9 & Pemotongan Ukuran Bare Core & 6 & 3,17 & 0,05485 & 0,165 & 0,150 & Normal \\
10 & Packing & 6 & 5,60 & 0,04320 & 0,197 & 0,150 & Normal \\
\hline
\end{tabular}

Tabel 3. Uji Kenormalan Data Bare Core $16 \mathrm{~mm}$

\begin{tabular}{cllccccc}
\hline No & \multicolumn{1}{c}{ Stasiun Kerja } & Subgrup & Mean & $\begin{array}{r}\text { Standar } \\
\text { Deviasi }\end{array}$ & KS & P-Value & $\begin{array}{c}\text { Hasil } \\
\text { Pengujian }\end{array}$ \\
\hline 1 & Pemotongan Balok Kayu & 6 & 5,57 & 0,05203 & 0,232 & 0,150 & Normal \\
2 & Penyrutan Dua Sisi Kayu Balok & 6 & 5,82 & 0,03656 & 0,197 & 0,150 & Normal \\
3 & Pembelahan Kayu Balok & 6 & 5,63 & 0,04834 & 0,221 & 0,150 & Normal \\
4 & Sortir & 6 & 3,00 & 0,09143 & 0,210 & 0,150 & Normal \\
5 & Penyusunan Kayu & 6 & 5,62 & 0,04457 & 0,363 & 0,150 & Normal \\
6 & Pemotongan Susunan Kayu & 6 & 5,14 & 0,08134 & 0,209 & 0,150 & Normal \\
7 & Pengeleman Pengepresan & 6 & 5,96 & 0,06186 & 0,167 & 0,150 & Normal \\
8 & Revisi & 6 & 2,99 & 0,03830 & 0,201 & 0,150 & Normal \\
9 & Pemotongan Ukuran Bare Core & 6 & 3,22 & 0,11940 & 0,202 & 0,150 & Normal \\
10 & Packing & 6 & 5,82 & 0,03656 & 0,197 & 0,150 & Normal \\
\hline
\end{tabular}

Untuk uji keseragaman data dan uji kecukupan datadilakukan untuk mencari N' dengan ketentuan data sudah mencukupi apabila $\mathrm{N}^{\prime}<\mathrm{N}$, dimana telah diketahui nilai $\mathrm{N}=30$. Setelah semua pengujian dinyatakan lulus uji, maka waktu siklus yang diperoleh dilanjutkan untuk menghitung rata-rata waktu siklus, dari rata-rata waktu 
siklus yang diperoleh dilanjutkan dengan menghitung waktu normal. Dalam perhitungan ini faktor penyesuaian seperti keterampilan, usaha, kondisi kerja, dan konsistensi dilibatkan dengan angka yang telah ditentukan berdasarkan sistem westing house.

Setelah waktu normal diperoleh akan dilanjutkan ke perhitungan waktu standar. Waktu standar diperoleh dengan memberikan nilai kelonggaran (allowance) berdasarkan kebutuhan operator yang dipertimbangkan oleh perusahaan. Allowance/kelonggaran ditentukan berdasarkan faktor-faktor yang berpengaruhyaitu tenaga kerja yang dikeluarkan, seperti dalam stasiun kerja pemotongan balok kayu tenaga yang dikeluarkan sangatlah banyak karena operator harus mengangkat balok-balok kayu untuk di potong menjadi beberapa bagian.Sedangkan untuk kelonggaran yang lainnya seperti sikap kerja, gerakan kerja, kelelahan mata, keadaan temperatur tempat kerja, keadaan lingkungan, keadaan atmosfir, dan kebutuhan pribadi nilai yang dikeluarkan hampir saja sama.

Waktu standar penyelesaian produk bare core dengan ketebalan $13 \mathrm{~mm}$ sebesar 65,30 menit dapat dilihat pada tabel 4 yang di konversi ke dalam jam menjadi 1,088 jam. Bare core dengan ketebalan $15 \mathrm{~mm}$ sebesar 66,02 menit (tabel 5), yang setelah dikonversikan menjadi 1,100 jam. Bare Core ketebalan $16 \mathrm{~mm}$ (tabel 6) mempunyai waktu standar 66,47 menit yang setelah dikonversi ke dalam jam menjadi 1,108 jam.

Tabel 4. Pengukuran Waktu Standar Bare Core $13 \mathrm{~mm}$

\begin{tabular}{|c|c|c|c|c|c|c|c|c|c|c|c|c|}
\hline \multirow{3}{*}{ No } & \multirow{3}{*}{ Stasium Kerja } & W. & \multicolumn{9}{|c|}{ Allowanane $(\mathrm{A})$ dalam persen $(\%)$} & \multirow{3}{*}{ 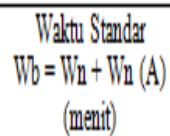 } \\
\hline & & Nomal & Tenaga yg & Sikap & Gerakan & Relelahan & Kerdaan & Readazan & Keadaan & Kebuthluan & $\mathrm{Im}$ A & \\
\hline & & (menit) & Dikeluatkan & Kerja & Keja & Mata & Temperatur & Amoserer & Limghkngen & Pribadi & & \\
\hline 1 & Pemotongan Balok Kayu & 6.38 & 10 & 2 & 3 & 2 & 3 & 2 & 5 & 2 & 29 & 8,24 \\
\hline 2 & Peaventan Dua Sisi Kayu Balok & 6.46 & 8 & 2 & 3 & 2 & 3 & 2 & 3 & 2 & 25 & 8,08 \\
\hline 3 & Pembelahan Kayu Balok & 6.13 & 9 & 2 & 3 & 2 & 3 & 2 & j & 2 & 28 & 7,85 \\
\hline 4 & Sortip & 3.01 & 6 & 2 & 2 & 2 & 2 & 2 & 2 & 2 & 20 & 3,61 \\
\hline$j$ & Penyusuman Kayu & 6.82 & 7 & 2 & 2 & 2 & 2 & 2 & 2 & 2 & 21 & 7,04 \\
\hline 6 & Pemotongan Susuman Kayu & 5.59 & 10 & 2 & 3 & 2 & 3 & 2 & 3 & 2 & 27 & 7,10 \\
\hline 7 & Pengeleman Pengepresan & 6.65 & 8 & 2 & 2 & 2 & 3 & 2 & 3 & 2 & 24 & 8,24 \\
\hline 8 & Rovisi & 2.90 & 7 & 2 & 2 & 2 & 2 & 2 & 2 & 2 & 21 & 3,51 \\
\hline 9 & Pemotongan Vhuran Brec Core & 3.58 & 1 & 2 & 3 & 2 & 3 & 2 & 3 & 2 & 24 & 4,43 \\
\hline 10 & Packing & 5.81 & 8 & 2 & 2 & 2 & 3 & 2 & 3 & 2 & 24 & 7,20 \\
\hline \multicolumn{12}{|c|}{ Total WWaktu Standary } & 66,30 \\
\hline
\end{tabular}

Tabel 5. Pengukuran Waktu Standar Bare Core $15 \mathrm{~mm}$

\begin{tabular}{|c|c|c|c|c|c|c|c|c|c|c|c|c|}
\hline \multirow[b]{2}{*}{ No } & \multirow[b]{2}{*}{ Stasiun Kerja } & \multicolumn{2}{|l|}{ W. } & \multicolumn{5}{|c|}{ Allowance $(\mathrm{A})$ dalam persen $(\%)$} & \multirow[b]{2}{*}{$\begin{array}{l}\text { Keadaan } \\
\text { Limgkngan }\end{array}$} & \multirow[b]{2}{*}{$\begin{array}{l}\text { Kebutuhan } \\
\text { Pribadi }\end{array}$} & \multirow[b]{2}{*}{$\mathrm{Jml} A$} & \multirow{2}{*}{$\begin{array}{c}\text { Waktu Standar } \\
W b=W_{n}+W_{n}(\mathrm{~A}) \\
\text { (menit) }\end{array}$} \\
\hline & & $\begin{array}{l}\text { Normal } \\
\text { (menit) }\end{array}$ & $\begin{array}{l}\text { Tenaga yg } \\
\text { Dikeluarkan }\end{array}$ & $\begin{array}{l}\text { Sikap } \\
\text { Kerja }\end{array}$ & $\begin{array}{c}\text { Gerakan } \\
\text { Kerja }\end{array}$ & $\begin{array}{c}\text { Kelelahan } \\
\text { Mata }\end{array}$ & $\begin{array}{c}\text { Keadaan } \\
\text { Temperatur }\end{array}$ & $\begin{array}{l}\text { Keadaan } \\
\text { Atmosfer }\end{array}$ & & & & \\
\hline 1 & Pemotongan Balok Kayu & 6.51 & 10 & 2 & 3 & 2 & 3 & 2 & 5 & 2 & 29 & 8,40 \\
\hline 2 & Penyerutan Dua Sisi Kayu Balok & 6.32 & 8 & 2 & 3 & 2 & 3 & 2 & 3 & 2 & 25 & 7,89 \\
\hline 3 & Pembelahan Kayu Balok & 6.11 & 9 & 2 & 3 & 2 & 3 & 2 & 5 & 2 & 28 & 7,82 \\
\hline 4 & Sortiv & 3.06 & 6 & 2 & 2 & 2 & 2 & 2 & 2 & 2 & 20 & 3,67 \\
\hline 5 & Penyusuman Kayu & 5.86 & 7 & 2 & 2 & 2 & 2 & 2 & 2 & 2 & 21 & 7,10 \\
\hline 6 & Pemotongan Susunan Kayu & 5.74 & 10 & 2 & 3 & 2 & 3 & 2 & 3 & 2 & 27 & 7,29 \\
\hline 7 & Pengeleman Pengepresan & 6.72 & 8 & 2 & 2 & 2 & 3 & 2 & 3 & 2 & 24 & 8,33 \\
\hline 8 & Revisi & 3.31 & 7 & 2 & 2 & 2 & 2 & 2 & 2 & 2 & 21 & 4,00 \\
\hline 9 & Pemotongan Ukuran Bare Core & 3.52 & 7 & 2 & 3 & 2 & 3 & 2 & 3 & 2 & 24 & 4,36 \\
\hline 10 & Packing & 5.77 & 8 & 2 & 2 & 2 & 3 & 2 & 3 & 2 & 24 & 7,16 \\
\hline \multicolumn{12}{|c|}{ Total Waktu Standar } & 66,02 \\
\hline
\end{tabular}


Tabel 6 Pengukuran waktu standar Bare Core $16 \mathrm{~mm}$

\begin{tabular}{|c|c|c|c|c|c|c|c|c|c|c|c|c|}
\hline \multirow[b]{2}{*}{ No } & \multirow[b]{2}{*}{ Stasiun Keja } & \multirow{2}{*}{$\begin{array}{l}\text { Waktu } \\
\text { Nomal } \\
\text { (menit) }\end{array}$} & \multicolumn{9}{|c|}{ Allowance (A) dalam persen $(\%)$} & \multirow{2}{*}{$\begin{array}{c}\text { W. Standar } \\
\text { Wb }=\text { Wn }+ \\
\text { Wn }(\mathrm{A}) \\
\text { (menit) }\end{array}$} \\
\hline & & & $\begin{array}{l}\text { Tenaga yg } \\
\text { Dikeluarkan }\end{array}$ & $\begin{array}{l}\text { Sikap } \\
\text { Kerja }\end{array}$ & $\begin{array}{l}\text { Gerakan } \\
\text { Kerja }\end{array}$ & $\begin{array}{c}\text { Kelelahan } \\
\text { Mata }\end{array}$ & $\begin{array}{l}\text { Keadaan } \\
\text { Temperatur }\end{array}$ & $\begin{array}{l}\text { Keadaan } \\
\text { Atmosfer }\end{array}$ & $\begin{array}{l}\text { Keadaan } \\
\text { Lingkungan }\end{array}$ & $\begin{array}{c}\text { Kebutuhan } \\
\text { Pribadi }\end{array}$ & $\begin{array}{c}\mathrm{Jml} \\
\mathrm{A}\end{array}$ & \\
\hline 1 & Pemotongan Balok Kayu & 6.51 & 10 & 2 & 3 & 2 & 3 & 2 & 5 & 2 & 29 & 8,40 \\
\hline 2 & Penynutan Dua Sisi Kayu Balok & 6.32 & 8 & 2 & 3 & 2 & 3 & 2 & 3 & 2 & 25 & 7.89 \\
\hline 3 & Pembelahan Kayu Balok & 6.11 & 9 & 2 & 3 & 2 & 3 & 2 & 5 & 2 & 28 & 7,82 \\
\hline 4 & Sortir & 3.06 & 6 & 2 & 2 & 2 & 2 & 2 & 2 & 2 & 20 & 3.67 \\
\hline 5 & Penyusuman Kayu & 5.86 & 7 & 2 & 2 & 2 & 2 & 2 & 2 & 2 & 21 & 7,10 \\
\hline 6 & Pemotongan Susunan Kayu & 5.74 & 10 & 2 & 3 & 2 & 3 & 2 & 3 & 2 & 27 & 7,29 \\
\hline 7 & Pengeleman Pengepresan & 6.72 & 8 & 2 & 2 & 2 & 3 & 2 & 3 & 2 & 24 & 8.33 \\
\hline 8 & Revisi & 3.31 & 7 & 2 & 2 & 2 & 2 & 2 & 2 & 2 & 21 & 4.00 \\
\hline 9 & Pemotongan Ukuran Bare Core & 3.52 & 7 & 2 & 3 & 2 & 3 & 2 & 3 & 2 & 24 & 4,36 \\
\hline 10 & Packing & 5.77 & 8 & 2 & 2 & 2 & 3 & 2 & 3 & 2 & 24 & 7,16 \\
\hline \multicolumn{12}{|c|}{ Total Waktu Standar } & 66,02 \\
\hline
\end{tabular}

\section{Analisis Rata-rata Penggunaan Tenaga Kerja}

Berdasarkan perhitungan pada tabel 7 didapat waktu standar yang telah dikonversikan ke dalam jam. Selanjutnya digunakan untuk menghitung man hours terpakai dengan mengalikan total peramalan masingmasing bare core dengan waktu standar tiap bare core. Total kebutuhan man hours terpakai yaitu sebesar $1.665 .184,956$.

Tabel 7. Kebutuhan Man Hours

\begin{tabular}{llll}
\hline Jenis Bare Core & $\begin{array}{l}\text { Total } \\
\text { Peramalan } \\
(\text { Jam) }\end{array}$ & $\begin{array}{l}\text { Waktu } \\
\text { Standar } \\
\text { (Jam) }\end{array}$ & $\begin{array}{l}\text { Kebutuhan } \\
\text { Man Hours } \\
\text { (Jam) }\end{array}$ \\
\hline Ketebalan 13 mm & 503.445 & 1,088 & 547.748 .160 \\
Ketebalan 15 mm & 402.486 & 1,100 & 442.734 .600 \\
Ketebalan 16 mm & 608.937 & 1,108 & 674.702 .196 \\
\hline \multicolumn{2}{l}{ Total Kebutuhan Man Hours (Jam) } & 1.665 .184 .956 \\
\hline
\end{tabular}

Jam kerja yang tersedia adalah rencana hari kerja setiap bulan yang telah ditetapkan oleh perusahaan selama satu tahun ke depan yang dikalikan dengan jam kerja biasa yaitu 8 jam kerja. Total rencana jam kerja tersedia satu shift selama satu tahun adalah 2360 jam.Dari total kebutuhan man hours dan total rencana jam kerja tersedia, kemudian dihitung rata-rata penggunaan tenaga kerja. Rata-rata tenaga kerja yang digunakan yaitu sebanyak 706 karyawan, dihitung dengan cara membagi jumlah jam tenaga kerja (man hours) dengan jam kerja yang tersedia pada periode yang lalu dan keduanya telah dihitung sebelumnya.

Jumlah rata-rata penggunaan tenaga kerja $=\frac{\text { Jumlah man hours terpakai }}{\text { Jumlah jam tersedia }}$

$$
\frac{1.665 .184,956}{2.360}=694,088 \approx 706
$$

Jadi, rata-rata penggunaan tenaga kerja untuk ketiga tipe bare core adalah 706 orang.

\section{Analisis Rencana Hari Kerja}

Rencana hari kerja efektif didasarkan pada rencana hari kerja yang telah direncanakan setiap bulannya dengan mempertimbangkan faktor tingkat kehadiran karyawan sebesar 95\%. Rencana hari kerja efektif terbesar yaitu 
terdapat pada bulan Mei2017dan April 2018 yaitu sebesar 26 hari kerja efektif, sedangkan hari kerja terkecil yaitu pada bulan Agustus 2017 sebesar 23 hari.Total rencana hari kerja efektif dengan persentase tingkat kehadiran yang telah ditetapkan oleh perusahaan sebesar 95\% yaitu sebanyak 283 hari kerja (tabel 9). Jumlah tersebut telah dipotong hari libur, baik ketetapan perusahaan atau hari libur nasional sebagai ketetapan pemerintah.

Tabel 8. Rekapitulasi Kebutuhan Bersih Ketiga Jenis Bare Core

\begin{tabular}{ccccccc}
\hline No & Tahun & Bulan & $\begin{array}{l}13 \mathrm{~mm} \\
\text { (Unit) }\end{array}$ & $\begin{array}{l}15 \mathrm{~mm} \\
\text { (Unit) }\end{array}$ & $\begin{array}{l}16 \mathrm{~mm} \\
\text { (Unit) }\end{array}$ & $\begin{array}{c}\text { Kebut Bersih } \\
\text { (Unit) }\end{array}$ \\
\hline 1 & 2017 & Mei & 42.875 & 35.375 & 51.120 & 129.370 \\
2 & 2017 & Juni & 41.875 & 33.750 & 53.766 & 129.391 \\
3 & 2017 & Juli & 39.281 & 31.406 & 44.667 & 115.354 \\
4 & 2017 & Agst & 37.813 & 28.969 & 46.376 & 113.158 \\
5 & 2017 & Sept & 46.242 & 34.617 & 59.003 & 139.862 \\
6 & 2017 & Okt & 44.664 & 34.375 & 56.877 & 135.916 \\
7 & 2017 & Nov & 37.979 & 30.221 & 44.535 & 112.444 \\
8 & 2017 & Des & 37.688 & 31.627 & 45.328 & 114.643 \\
9 & 2018 & Jan & 38.943 & 31.697 & 47.995 & 118.635 \\
10 & 2018 & Feb & 46.021 & 35.790 & 56.126 & 137.937 \\
11 & 2018 & Mar & 46.410 & 38.366 & 55.970 & 140.746 \\
12 & 2018 & Apr & 43.655 & 36.293 & 47.173 & 127.121 \\
\hline \multicolumn{7}{c}{ Jumlah } \\
\hline \multicolumn{7}{c}{}
\end{tabular}

Tabel 9.Perhitungan Rencana Hari Kerja

\begin{tabular}{clcccc}
\hline Tahun & Bulan & $\begin{array}{c}\text { Jumlah } \\
\text { Hari }\end{array}$ & $\begin{array}{c}\text { Tingkat } \\
\text { Kehadiran } \\
\text { Karyawan }\end{array}$ & $\begin{array}{c}\text { Hari Kerja } \\
\text { Efektif }\end{array}$ & $\begin{array}{c}\text { Hari Kerja } \\
\text { Efektif }\end{array}$ \\
\hline 2017 & Mei & 26 & $95 \%$ & 24.7 & 25 \\
2017 & Juni & 25 & $95 \%$ & 23.75 & 24 \\
2017 & Juli & 24 & $95 \%$ & 22.8 & 23 \\
2017 & Agustus & 23 & $95 \%$ & 21.85 & 22 \\
2017 & September & 25 & $95 \%$ & 23.75 & 24 \\
2017 & Oktober & 24 & $95 \%$ & 22.8 & 23 \\
2017 & November & 25 & $95 \%$ & 23.75 & 24 \\
2017 & Desember & 24 & $95 \%$ & 22.8 & 23 \\
2018 & Januari & 24 & $95 \%$ & 22.8 & 23 \\
2018 & Februari & 25 & $95 \%$ & 23.75 & 24 \\
2018 & Maret & 24 & $95 \%$ & 22.8 & 23 \\
2018 & April & 26 & $95 \%$ & 24.7 & 25 \\
\hline \multicolumn{5}{c}{ Total } \\
\hline
\end{tabular}

\section{Perencanaan Produksidengan Metode Zero Inventory}

Dalam perencanaan zero inventorysetiap bulannya dalam cakupan periode perencanaan, perusahaan hanya memproduksi sejumlah yang dibutuhkan konsumen dengan tidak mengikutsertakan persediaan. Jumlah tenaga kerja akan bertambah ketika kebutuhan permintaan naik dan akan dilakukan pemecatan tenagakerja ketika kebutuhan atau permintaanmenurun.Biasanya untuk membuat suatu perencanaan produksi yang fleksibel 
digunakan tenaga kerja sub kontrak atau pada perusahaan yang memanfaatkan bursa tenaga kerja, sehingga terlihat jelas bahwa jumlah penggunaan tenaga kerja yang seharusnya dalam setiap bulan perencanaan.

1. Hari Kerja Efektif. Hari kerja efektif pada setiap bulan dalam cakupan periode perencanaan merupakan hasil perkalian antara jumlah hari kerja dalam setiap bulan dengan rata-rata tingkat kehadiran karyawan dengan total hari kerja adalah 283 hari. Rincian hari kerja efektif dapat dilihat pada tabel 9.

2. Kemampuan Tenaga Kerja. Kemampuan seorang tenaga kerja dalam setiap bulannya sama dengan jumlah produk yang dihasilkan seorang tenaga kerja dalam sehari dikalikan dengan jumlah hari kerja yang tersedia pada bulan tersebut. Kemampuan tenaga kerja per hari diperoleh dari jumlah unit agregasi di bagi dengan perkalian antara hari kerja efektif dengan jumlah tenaga kerja. Adapun kemampuan tenaga kerja setiap harinya yaitu sebesar 8 unit/hari/tenaga kerja. Dalam hal ini kemampuan tenaga kerja setiap bulan tergantung dari hari kerja yang tersedia. Adapun kemampuan tenaga kerja terbesar dalam rencana produksi terdapat pada bulan Mei 2017 dan April 2018 yaitu sebesar 200 unit. Dengan total seluruh kemampuan dalam satu tahun adalah 2.360 unit/tenaga kerja.

3. Permintaan. Besarnya kebutuhan produk bare core setiap bulannya dalam periode perencanaan yang terdapat pada tabel 8 dihitung dengan cara menentukan jumlah kebutuhan. Kebutuhan bare core dikalikan dengan faktor agregasi produk, sehingga diperoleh kebutuhan bersih dalam setiap bulan dari beberapa produk yang diagregasi tersebut. Dalam prencanaan ini total keseluruhan kebutuhan/permintaan dalam satu tahun sebesar 1.514.868unit.

4. Tenaga Kerja yang dibutuhkan. Jumlah tenaga kerja dalam perencanaan zero inventory sangat bervariatif, meyesuaikan dengan jumlah permintaan setiap bulannya. Dalam perencanaan ini, tenaga kerja yang dibutuhkan dihasilkan dari permintaan dibagi dengan kemampuan tenaga kerja, seperti pada tabel dibawah ini kebutuhan tenaga kerja pada bulan April 2018 mencapai 665 tenaga kerja karena permintaannya mencapai 127.121 unit yang dibagi oleh kemampuan tenaga kerja sebesar 200 unit/tenaga kerja. Bulan November 2017 merupakan bulan yang tingkat kebutuhan tenaga kerjanya sedikit. Jumlah tenaga kerja terbesar terdapat pada periode bulan November 2017 mencapai 613 tenaga kerja. Dengan total keseluruhan tenaga kerja dalam satu tahun adalah 8.382 tenaga kerja. Dalam perencanaan Zero Inventory dalam setiap bulannya akan terjadi pengangkatan dan pemberhentian tenaga kerja yang digunakan, karena kebutuhan tenaga kerja disesuaikan dengan kebutuhan permintaan produk, seperti dalam tabel berikut.

Tabel 10. Kebutuhan Tenaga Kerja Perencanaan Zero Inventory

\begin{tabular}{clcccc}
\hline Thn & Bulan & $\begin{array}{c}\text { Dibutuh- } \\
\text { kan }\end{array}$ & Yg Ada & $\begin{array}{l}\text { Penam- } \\
\text { bahan }\end{array}$ & PHK \\
\hline 2017 & Mei & 677 & 834 & & 157 \\
2017 & Juni & 704 & 677 & 27 & \\
2017 & Juli & 654 & 704 & & 50 \\
2017 & Agst & 669 & 654 & 15 & \\
2017 & Sept & 761 & 669 & 92 & \\
2017 & Okt & 770 & 761 & 9 & 157 \\
2017 & Nov & 613 & 770 & & \\
2017 & Des & 650 & 613 & 36 & \\
2018 & Jan & 672 & 650 & 22 & \\
2018 & Feb & 750 & 672 & 78 & \\
2018 & Mar & 798 & 750 & 47 & \\
2018 & Apr & 665 & 798 & & 558 \\
\hline \multicolumn{7}{c}{ Jumlah } & 8382 & 8552 & 326 & \\
\hline
\end{tabular}


5. Biaya Tenaga Kerja.Dalam hubungannya dengan tenaga kerja yang dibutuhkan setiap bulannya baik itu tenaga kerja yang digunakan, tenaga kerja yang angkat, ataupun tenaga kerja yang di PHK semuanya terkait dengan biaya-biaya didalamnya. Adapun biaya tenaga kerja sebesar Rp.13.464/jam, seperti pada bulan Maret 2018 jumlah tenaga kerja yang dibutuhkan sebesar 798 dikalikan dengan biaya tenaga kerja menghasilkan Rp 1.976.925.300. Biaya penambahan tenaga kerja Rp.200.000/tenaga kerja dapat dilihat tabel 11Pada bulan September 2017 dilakukan penambahan tenaga kerja sebanyak 92 tenaga kerja dikalikan dengan biaya pengangkatan menghasilkan biaya sebesar Rp.18.400.000. Biaya pada bulan Mei dan November 2017 jumlah tenaga kerja yang di PHK sebanyak 157 tenaga kerja dikalikan dengan biaya PHK menghasilkan biaya sebesar Rp. 704.063.360. Adapun rekapitulasi mengenai kebutuhan biaya terkait tenaga kerja adalah sebagai berikut:

Tabel 11. Biaya Tenaga Kerja Perencanaan Zero Inventory

\begin{tabular}{ccccc}
\hline Tahun & Bulan & $\begin{array}{c}\text { Biaya Tenaga } \\
\text { Kerja } \\
(\mathrm{Rp})\end{array}$ & $\begin{array}{c}\text { Biaya } \\
\text { Penambahan } \\
\text { Tenaga Kerja }\end{array}$ & $\begin{array}{c}\text { Biaya PHK } \\
\text { Tenaga Kerja }\end{array}$ \\
\hline 2017 & Mei & 1.602 .621 .480 & & 704.063 .360 \\
2017 & Juni & 1.666 .536 .960 & 5.400 .000 & \\
2017 & Juli & 1.548 .174 .960 & & 224.224 .000 \\
2017 & Agst & 1.583 .683 .560 & 3.000 .000 & \\
2017 & Sept & 1.801 .469 .640 & 18.400 .000 & \\
2017 & Okt & 1.822 .774 .800 & 1.800 .000 & \\
2017 & Nov & 1.451 .118 .120 & & 704.063 .360 \\
2017 & Des & 1.538 .706 .000 & 7.200 .000 & \\
2018 & Jan & 1.664 .779 .200 & 4.400 .000 & \\
2018 & Feb & 1.858 .012 .500 & 15.600 .000 & \\
2018 & Mar & 1.976 .925 .300 & 5.400 .000 & \\
2018 & Apr & 1.647 .437 .750 & & 596.435 .840 \\
\hline \multicolumn{6}{c}{ Jumlah } & 20.162 .240 .270 & 65.200 .000 & 2.228 .786 .560 \\
\hline
\end{tabular}

\section{KESIMPULAN}

Perencanaan yang tepat untuk jumlah tenaga kerja yang digunakan setiap bulan yang bersifat konstan yaitu sebanyak 706 tenaga kerja.Pada bulan Mei 2017 biaya yang dikeluarkan perusahaan untuk tenaga kerja adalah paling besar yaitu Rp. 2.245.248.880 yang dihasilkan dari jumlah tenaga kerja yang dibutuhkan sebesar 706 orang, dikalikan dengan hari kerja efektif sebanyak 25 hari dikali 8 jam kerja/hari dan dikalikan biaya tenaga kerja.

Jumlah biaya total yang dikeluarkan dalam setiap periode perencanaan zero inventory merupakan hasil penjumlahan dari biaya tenaga kerja, biaya pengangkatan tenaga kerja dan biaya PHK tenaga kerja.Biaya yang dikeluarkan perusahaan pada bulan Mei 2017 adalah paling besar yaitu sebesar Rp. 2.306.684.840 sedangkan 
biaya terkecil terdapat pada bulan Desember 2017 sebesar Rp. 1.545.906.000. Sehingga pada bulan Mei 2017 perlu dilakukan PHK (pengurangan tenaga kerja) untuk mengurangi pengeluaran.

Tenaga kerja disini adalah karyawan yang memang sudah memenuhi kemampuan saat melaksanakan pekerjaannya, dan dalam hal ini usulan ini dibatasi hanya perhitungan biaya untuk produksi yang tepat, belum melakukan perhitungan investasi pelatihan karyawan, perekrutan, dan biaya yang ditimbulkan dari PHK.

\section{DAFTAR PUSTAKA}

Achmad F.K.W. (2018). Ekspor Kayu Lapis ke Korsel, Pasar Menggiurkan bagi Indonesia.https://ekonomi.kompas.com/read/2018/05/28/165140426/. Diakses 19 Agustus 2018

AgroIndonesia. (2018). Peluang Pasar Kayu Lapis AS.http://agroindonesia.co.id/2018/03/peluangpasar-kayu-lapis-as/. Diakses 19 Agustus 2018

Andini, R. A., \& Simatupang, T. M. A process simulation of inventory planning and control for minute maid pulpy at coca cola. Journal of Int. J. Logistics Systems and Management.Retrieved from http://www.academia.edu

Biegel, John, E. (2000). Pengendalian produksi : Suatu pendekatan kualitatif, Akademika Pressindo, Jakarta.

Buffa, E., S \& Rakesh, K. Sarin. (1998). Manajemen operasi dan produksi modern, Jilid 1 edisi kedelapan, Binarupa Aksara, Jakarta.

Carlos, A., \& Castro, Z. (2012). Spreadsheets to teach the (RP,Q) model in an inventory management course. Journal of Production Engineering Department, Universidad Eafit Medellin Colombia.Retrieved from http://www.pomsmeetings.org

Gaspersz, V. (2008). Production planning \& inventory control, Gramedia, Jakarta.

Hanczar, P., \& Jakubiak, M. (2011). Aggregate planning in manufacturing company - linear programming aproach. Journal of Total Logistic Management, 4, 69-76.

Khairani, D. (2013). Perencanaan dan pengendaliaan produksi, Graha Ilmu, Yogyakarta.

M Lei, Z Yin, S Li, \& Q Tan. (2017). Intermittent demand forecasting and inventory control with multiple temporal and cross-sectional aggregation and disaggregation methods. $201713^{\text {th }}$ International Conference on Natural Computation, Fuzzy Systems and Knowledge Discovery(ICNC-FSKD), IEEE Xplore.

Nasution, A. H. (2008), Perencanaan dan pengendalian produksi, Graha Ilmu, Yogyakarta. 
Sipper, D., \& Bulfin, Jr, Robert, L. (1998) Production: planning, control and integration, The McGraw-Hill, USA.

Sinulingga, S.(2009), Perencanaan dan pengengendalian produksi, Graha Ilmu, Yogyakarta.

Sutalaksana, I.Z., \& Anggarwisastra, R., \& Tjakraatmadja, J. H. (2006). Teknik perancangan sistim kerja, Edisi Kedua, ITB, Bandung.

Lampiran: Perhitungan Perencanaan dengan MetodeZero Inventory

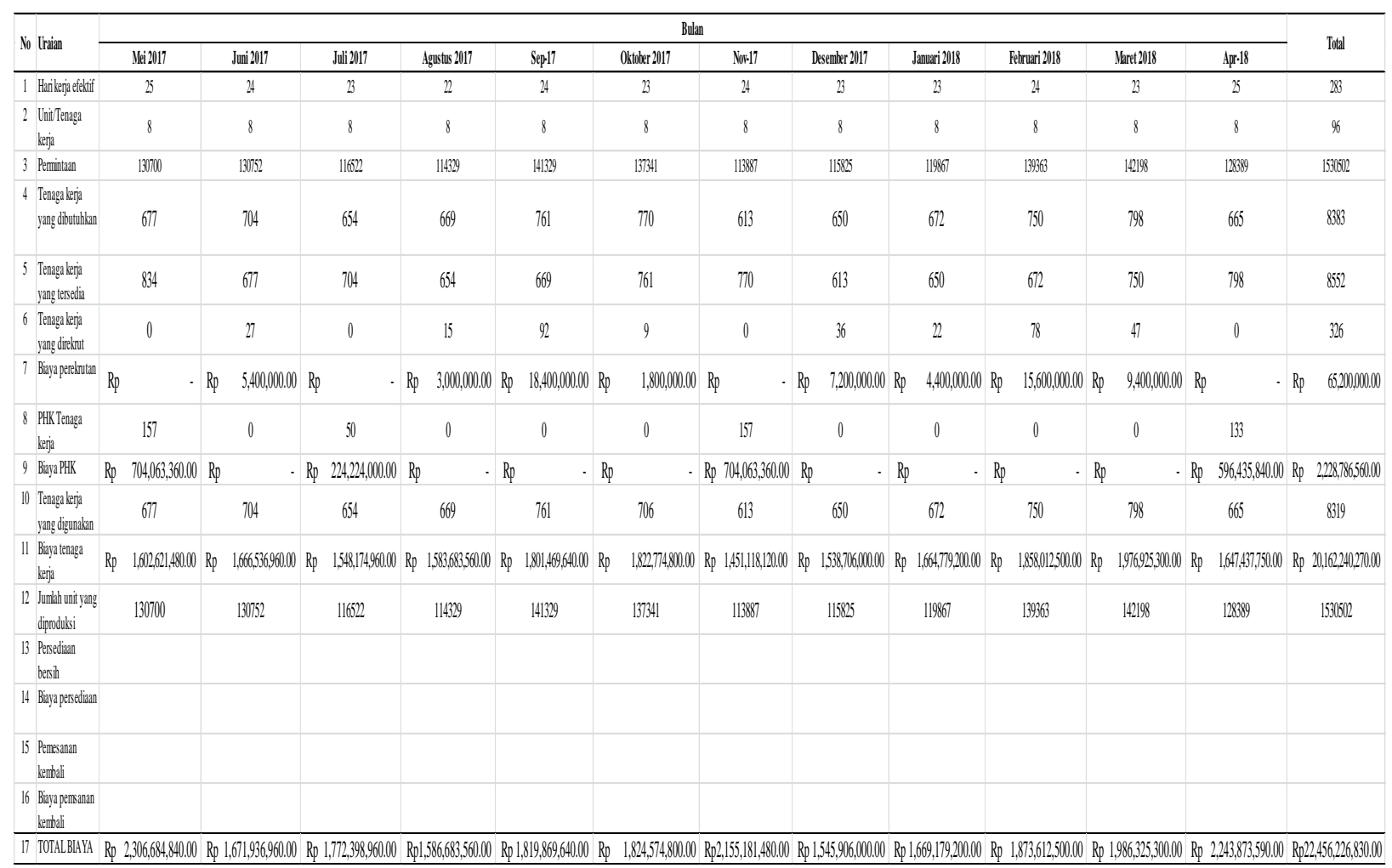

